\title{
Śmierć jako źródło i przedmiot prawa. Stanowisko Thomasa Hobbesa
}

\section{Część I: Śmierć jako źródło prawa}

Wstęp. W dziejach filozofii często uznawano śmierć (zwłaszcza świadomość śmierci i lęk przed nią) za cechę definicyjną człowieka. Starożytni Grecy określali ludzi mianem śmiertelnych w opozycji do nieśmiertelnych bogów, dwudziestowieczni egzystencjaliści zaś akcentowali indywidualną świadomość śmierci, odróżniającą nas od innych bytów. Niezależnie od trafności tych opisów uznanie człowieka za istotę śmiertelną (homo mortalis) czy wręcz skazaną na śmierć (homo moriturus) ${ }^{1}$ prowadzi do pytań praktycznych, związanych z regulacjami prawnymi dotyczącymi śmierci. Pytania te podjął Thomas Hobbes, zdaniem którego lęk przed śmiercią jest głównym źródłem państwa i prawa.

Hobbes nie poświęcił wiele uwagi metafizycznym kwestiom śmierci, definiując ją - zgodnie z ówczesnym stanem wiedzy - jako nieodwracalny kres życia, będącego ruchem krwi w żyłach i arteriach ${ }^{2}$. Szerzej badał problemy

\footnotetext{
${ }^{1}$ Moriturus znaczy dosłownie „wleczony na śmierć”; słowem tym określano rzymskich gladiatorów, udających się na arenę.

${ }^{2}$ R. Tokarczyk, Hobbes, Warszawa 1987, s. 42. Hobbes sądził zarazem, że mechanicystyczna teoria życia rodzi nadzieję na potencjalnie nieskończone przedłużanie życia na ziemi; jeżeli bowiem organizm jest maszyną, to zużyte elementy można zastępować nowymi. Idea ta była także bliska Kartezjuszowi.
} 
eschatologiczne - zmartwychwstanie, zbawienie i potępienie ${ }^{3}$, niewątpliwie jednak najważniejsze były dla niego kwestie związane z uprawnieniami i zobowiązaniami wynikającymi ze śmiertelności. Zagadnienia te, dyskutowane już przez Platona i Arystotelesa, odżyły w Renesansie; przykładem Thomas Morus dyskutujący w swojej Utopii problem eutanazji, kary śmierci, prawa do zabójstwa i samobójstwa. Najbardziej jednak wszechstronnie podjął te kwestie Hobbes, według którego śmierć jest źródłem oraz przedmiotem umowy społecznej, stanowiąc podstawę państwa i prawa.

Celem obecnego artykułu jest rekonstrukcja i ocena argumentacji rozwiniętej przez Hobbesa, związanej z ustanowieniem prawa oraz jego konkretnymi przepisami, dotyczącymi śmierci. W części pierwszej (Śmierć jako źródło prawa) podejmiemy problem lęku przed śmiercią jako podstawy prawa, w drugiej natomiast (Śmierć jako przedmiot prawa) wskażemy na konkretne regulacje dotyczące zabójstwa w obronie własnej, kary śmierci, reguł prowadzenia wojny, męczeństwa, racjonalności ofiary za drugiego oraz samobójstwa.

Stan natury. Ponieważ, według Hobbesa, głównym celem człowieka jest zachowanie życia ${ }^{4}$, śmierć należy uznać za największe zło ${ }^{5}$ :

człowiekowi, który zbyt daleko patrzy przed siebie w trosce o przyszłość, obawa śmierci, biedy i innego nieszczęścia zżera serce całymi dniami; i nie ma on spoczynku ani przerwy w swym niepokoju, poza snem .

Boimy się zwłaszcza śmierci gwałtownej, zadanej przez innych, która w stanie natury nieustannie nam zagraża. Dopóki bowiem nie istnieje państwo ani przepisy prawa chroniące życie, groźba bycia zabitym jest bardziej realna niż zgon naturalny, wynikający z praw przyrody. Skoro zaś śmierć może nas spotkać w każdej chwili z ręki dowolnej osoby, musimy poświęcić

\footnotetext{
${ }^{3}$ Hobbes negował nieśmiertelność duszy, uznawał jednak za możliwe - z racji wszechmocy Boga - wskrzeszenie ciał; rozważał też kwestie wiecznego zbawienia i potępienia. Pisałem na ten temat w artykule Eschatologia Thomasa Hobbesa, złożonym do druku w czasopiśmie „Analiza i Egzystencja”.

${ }^{4}$ J. C. A. Gaskin, Wprowadzenie, [w:] T. Hobbes, Lewiatan, czyli materia, forma $i$ władza państwa kościelnego i świeckiego, przeł. C. Znamierowski, Warszawa 2009, s. 33.

${ }^{5}$ A. P. Martinich, Hobbes, New York - London 2005, s. 23; S. Kijaczko, Wobec bycia. Filozoficzny problem samobójstwa, Opole 2005, s. 132.

${ }^{6}$ T. Hobbes, Lewiatan, s. 188.
} 
wszystkie siły na obronę siebie. Nasz los przypomina sytuację kapłanów starożytnej bogini Diany, którzy zdobywali swój urząd, zabijając poprzednika, musieli jednak bronić swej pozycji przed następcą mogącym nadejść w dowolnej chwili. Ciągła niepewność powodowała, że kapłan nigdy nie mógł się czuć bezpieczny ${ }^{7}$. Podobnie w stanie natury każdy zdany jest na siebie, widząc w innym potencjalnego zabójcę. Dopóki bowiem nie ma władzy, panuje wojna wszystkich ze wszystkimi ${ }^{8}$, niekoniecznie w sensie czynnej walki, lecz przynajmniej w sensie gotowości do niej9. W tej sytuacji nie ma możliwości pracy, handlu ani budowania, człowiek nie wie bowiem, czy jakiekolwiek przedsięwzięcie doprowadzi do końca; dlatego stan natury to największe nieszczęście, jakie może nas spotkać ${ }^{10}$.

Jednym ze źródeł wojny jest brak dostatecznej ilości dóbr ${ }^{11}$, o które musimy walczyć a zdobywszy je - bronić ich. Zachodzi zatem istotna różnica między koncepcją stanu natury u Hobbesa a tą, którą później rozwijał Rousseau, głosząc harmonię człowieka i przyrody, gwarantującą nam zaspokojenie potrzeb naturalnych; według Hobbesa stan natury oznacza brak dostatecznej ilości dóbr, rodząc walkę o przetrwanie.

Innym źródłem wojny są namiętności ${ }^{12}$, zwłaszcza chęć posiadania większej ilości dóbr, niż te, które są potrzebne do życia ${ }^{13}$ : „[... pożądliwość i namiętności ludzkie sprawiają, iż gdyby ludzi nie zmuszała jakaś moc i władza, to stale zwalczaliby się w wojnach"14. Skoro zaś istotą życia są namiętności, to człowiek, w którym wszelkie pożądania uległyby zanikowi, powinien być

${ }^{7}$ J. G. Frazer, Złota gałąź, przeł. H. Krzeczkowski, t. 1, Warszawa 1971, s. 25-27.

8 „Jest [...] oczywiste, że gdy ludzie żyją, nie mając nad sobą mocy, która by ich wszystkich trzymała w strachu, to znajdują się w stanie, który się zwie wojną; i to w stanie takiej wojny, jak gdyby każdy był w wojnie z każdym innym”. T. Hobbes, Lewiatan, s. 206-207. „Oto bowiem między ludźmi, nad którymi nie ma władzy, jest nieustannie wojna każdego człowieka z jego sąsiadami”. Tamże, s. 301.

${ }_{9}$ Tamże, s. 207; J. Rawls, Wykłady z historii filozofii polityki, oprac. S. Freeman, przeł. S. Szymański, Warszawa 2010, s. 92, 101.

${ }^{10}$ T. Hobbes, Lewiatan, s. 207, 420.

${ }^{11}$ J. Rawls, Wykłady z historii filozofii polityki, s. 95, 101; A. P. Martinich, Hobbes, s. 67.

${ }^{12}$ J. Rawls, Wykłady z historii filozofii polityki, s. 92.

${ }^{13} \mathrm{~W}$ De Cive pisał, że w stanie natury człowiek musi mieć środki do zachowania swego życia, takie jak pokarm; nikt nie powinien ich gromadzić zbyt wiele, zwłaszcza, gdyby innym miało ich brakować. T. Hobbes, On the Citizen, edited and translated by R. Tuck, Cambridge 2010, s. 48; R. Tuck, Hobbes. A Very Short Introduction, Oxford 2002, s. 81-82.

${ }^{14}$ F. C. Copleston, Historia filozofii, t. 5: Od Hobbesa do Hume 'a, przeł. J. Pasek, J. Pasek, P. Józefowicz, Warszawa 2005, s. 18. 
uznany za martwego, życie nie polega bowiem na spokoju i bezruchu ${ }^{15}$. W tym opisie możemy upatrywać zalążków późniejszych teorii, rozwijanych przez Schopenhauera i Nietzschego, akcentujących irracjonalną wolę jako podstawę świata. Stan natury jest zatem daleki od doskonałości, co musiał także przyznać Rousseau, widząc w chciwości podstawę społeczeństwa; ten bowiem, kto wytyczył skrawek ziemi, nazywając go własnym, zniszczył harmonię człowieka i przyrody, tworząc wszelkie nierówności. W teorii Rousseau problemem jest jednak, jak w doskonałym świecie takie zaburzenie było w ogóle możliwe ${ }^{16}$; teoria Hobbesa, odwołująca się do naturalnej pożądliwości, jest od tej trudności wolna.

Kolejnym źródłem wojny jest równość ludzi pod względem mocy, polegająca nie na takiej samej sile fizycznej, lecz na tym, że nawet najsłabszy (dzięki inteligencji i sprytowi) potrafi zabić najsilniejszego ${ }^{17}$. Równość oznacza też, że w stanie natury każdy jest sędzią w swojej sprawie, oceniając stopień zagrożenia ze strony innych ${ }^{18}$. Znaczy to, że mam prawo podejrzewać każdego o chęć zabicia mnie lub zabrania mi dobytku ${ }^{19}$, co usprawiedliwia podjęcie przeze mnie działań obronnych, z zabójstwem prewencyjnym innych włącznie ${ }^{20}$.

Dalszym źródłem wojny jest egoizm ${ }^{21}$, każdy ma bowiem trzy podstawowe interesy: zachowanie swego życia, dobro bliskich (przede wszystkim małżon-

\footnotetext{
${ }^{15}$ Nie należy zatem definiować szczęścia jako spokoju umysłu. T. Hobbes, Lewiatan, s. 177.

${ }^{16}$ Pierwotna kradzież na gruncie teorii Rousseau jest równie niezrozumiała, jak opisany w Księdze Rodzaju upadek człowieka, mający miejsce w doskonałym świecie stworzonym przez Boga.

${ }^{17}$ T. Hobbes, Lewiatan, s. 204. Zdaniem niektórych jest to okrutny żart Hobbesa. A. P. Martinich, Hobbes, s. 65. Jeśli przyjąć taką interpretację, to żart ów należałoby odczytywać jako polemikę z Kartezjuszem, którego Rozprawa o metodzie rozpoczyna się następująco: „Rozsądek jest to rzecz ze wszystkich na świecie najlepiej rozdzielona, każdy bowiem sądzi, że jest w nią tak dobrze zaopatrzony, iż nawet ci, których we wszystkim innym najtrudniej jest zadowolić, nie zwykli pragnąć go więcej, niźli posiadają". Kartezjusz, Rozprawa o metodzie właściwego kierowania rozumem i poszukiwania prawdy w naukach, przeł. T. Żeleński (Boy), Warszawa 1980, s. 29. Można też argumentować, że równość ludzi na gruncie teorii Hobbesa oznacza ich jednakową bezbronność wobec agresora.

${ }_{18}$ T. Hobbes, Lewiatan, s. 220.

19 Tamże, s. 205.

${ }^{20}$ R. Tuck, The Rights of War and Peace. Political Thought and the International Order From Grotius to Kant, Oxford 2009, s. 130.

${ }^{21}$ J. Rawls, Wykłady z historii filozofii polityki, s. 97.
} 
$\mathrm{ka})^{22} \mathrm{i}$ wygodę ${ }^{23}$. Egoizm jest zwykle napiętnowany jako wykorzystywanie innych, zdaniem Hobbesa jednak nie ma on charakteru moralnego, lecz metafizyczny; egoizm jest zatem nieuchronny ${ }^{24}$, ponieważ dążenie do zachowania siebie i obrony swych interesów to skutek instynktu, co ilustruje przywołana w De Cive analogia ze spadającym kamieniem:

każdy człowiek pożąda tego, co jest dla niego dobre, i unika tego, co jest złe, a przede wszystkim głównego zła naturalnego, którym jest śmierć; a czyni to pod wpływem pewnego impulsu natury, podobnie jak kamień spada w dó ${ }^{25}$.

Głównym źródłem egoizmu jest zatem naturalne dążenie do zachowania siebie, zwane conatus ${ }^{26}$. Jest to cecha wszystkich bytów (także nieożywionych), która w człowieku przejawia się dążeniem do obrony swego ciała oraz panowania nad innymi ${ }^{27}$.

Egoizm nie oznacza jednak okrucieństwa wobec innych ludzi. Wprawdzie nie odczuwamy naturalnej do nich sympatii czy przyjaźni, to jednak nie jesteśmy z natury złośliwi ani nie cieszymy się z cudzego cierpienia ${ }^{28}$. Nie ma też w człowieku dążenia do bezinteresownego zabijania; podejmujemy walkę tylko dlatego, że inni są dla nas zagrożeniem. „Tego [...] iżby człowiek jakiś mógł znajdować przyjemność w wielkich krzywdach, jakich doznają inni ludzie, nie mając w tym żadnej własnej korzyści, tego sobie nie mogę pomyśleć" ${ }^{29}$. Zdaniem Hobbesa człowiek jest także zdolny do działań sprawiedli-

\footnotetext{
${ }^{22}$ Uczucia małżeńskie Hobbes uznawał za drugie w porządku ważności po pragnieniu zachowania siebie i miłości własnej. Tamże, s. 91, 97. Rozwiązanie takie wiązało się prawdopodobnie z ówczesnym modelem rodziny, która była przede wszystkim kontraktem majątkowym.

${ }^{23}$ Tamże, s. 98.

${ }^{24}$ Tezę egoizmu uznawał Hobbes za tautologię. S. J. Finn, Hobbes: a Guide for the Perplexed, London - New York 2007, s. 6, 52.

${ }^{25}$ Cyt. za: J. C. A. Gaskin, Wprowadzenie, s. 33. Przytoczony tekst znajduje się na stronie 27 cytowanego wyżej wydania angielskiego On the Citizen.

${ }^{26}$ A. P. Martinich, Hobbes, s. 29-30. Conatus to najmniejszy możliwy ruch, którego nie da się zmierzyć ani zauważyć. Hobbes nazywał te ruchy słowem endeavours, co sugeruje aktywne dążenie do czegoś. Tamże.

${ }^{27}$ Tamże, s. 29; S. Kijaczko, Wobec bycia, s. 132. Conatus był popularną ideą w XVII wieku, szczególnie wyraźnie obecną w tekstach Spinozy, zdaniem którego dążenie do zachowania własnego bytu stanowi treść istotną każdej rzeczy. B. Spinoza, Etyka, [w:] B. Spinoza, Traktaty, przeł. I. Halpern-Myślicki, Kęty 2000, (część III, twierdzenia 6-8).

${ }^{28}$ J. Rawls, Wykłady z historii filozofii polityki, s. 86.

${ }^{29}$ T. Hobbes, Lewiatan, s. 137.
} 
wych z szacunku dla sprawiedliwości ${ }^{30}$, niekiedy zaś woli narazić siebie na niebezpieczeństwo, niż mścić się na innych ${ }^{31}$. Sugeruje to, że egoizm natury ludzkiej ma istotne ograniczenia.

Stan natury to nie stan historyczny ${ }^{32}$, lecz metafizyczny, odzwierciedlający istotę człowieka; jest on jednak zawsze możliwy, urzeczywistniając się w sytuacji braku władzy ${ }^{33}$. Zdaniem Hobbesa istnieje wiele miejsc go przypominających, chociażby Ameryka, gdzie ludzie żyją jak zwierzęta, bez żadnych regulacji prawnych ${ }^{34}$. Jeszcze wyraźniejszy przykład stanowi wojna domowa, oznaczająca śmierć państwa ${ }^{35}$. Ilustracją stanu natury były także obyczaje Persów opisane przez Sekstusa Empiryka w dziele Przeciw uczonym. W chwili śmierci króla Persowie zawieszali wszelkie zakazy, chcąc ukazać obywatelom konieczność prawa ${ }^{36}$. Przykłady te świadczą, że hipotezę wojny wszystkich ze wszystkimi można potwierdzić empirycznie ${ }^{37}$. Przede wszystkim jednak znamy ją z własnego doświadczenia, kładąc się bowiem spać, zamykamy dom na klucz, udając się zaś w podróż, zbroimy się przed ewentualnymi agresorami ${ }^{38}$. Powodem jest fakt, że sami nastajemy na dobytek oraz życie innych, spodziewając się podobnych zachowań $\mathrm{z}$ ich strony.

Prawo do życia w stanie natury. Stan natury ukazuje nędzę człowieka, gwarantuje nam jednak wszelkie prawa, zwłaszcza prawo do życia. Jego źródłem jest biologiczny instynkt przetrwania, wyrażający się w bezwarunkowym pragnieniu zachowania siebie ${ }^{39}$.

${ }^{30}$ J. Rawls, Wykłady z historii filozofii polityki, s. 97.

${ }^{31}$ T. Hobbes, Lewiatan, s. 236.

${ }^{32}$ Tamże, s. 208-209.

${ }^{33}$ J. Rawls, Wykłady z historii filozofii polityki, s. 82.

${ }^{34}$ T. Hobbes, Lewiatan, s. 209. Widać tu europocentryzm Hobbesa, charakterystyczny dla wielu myślicieli, uznających ludy żyjące na innych kontynentach za prymitywne. W tradycji europejskiej istniał jednak także inny nurt myśli, w którym akcentowano doskonałość ludów prymitywnych i z ich perspektywy krytykowano instytucje zachodnie; przykładem są Listy perskie Monteskiusza.

35 T. Hobbes, Lewiatan, s. 82, 209. Hobbes przeżył wojnę domową w Anglii, kiedy to obalono króla Karola I, skazując go na śmierć.

${ }^{36}$ Tamże, s. 209, przypis.

${ }^{37}$ M. Kuniński, Problem stanu natury i stanu politycznego w teorii umowy społecznej Thomasa Hobbesa, [w:] Z. Rau, M. Chmieliński (red.), Umowa społeczna i jej krytycy w myśli politycznej i prawnej, Warszawa 2010, s. 111-112, 117.

${ }^{38}$ T. Hobbes, Lewiatan, s. 208.

${ }^{39}$ Tamże, s. 426. 
Teza ta nie była oryginalna, już bowiem Tomasz z Akwinu mówił, że każdy kocha przede wszystkim własny byt, dążąc do jego zachowania, podobnie zaś argumentowali myśliciele renesansowi, chociażby Montaigne czy Lipsius ${ }^{40}$. W filozofii Hobbesa jednak zasada ta odgrywała ważniejszą rolę, dążenie do ocalenia swego życia traktował on bowiem nie tylko jako opis człowieka, lecz także jako nasze fundamentalne i naturalne prawo ${ }^{41}$. Jest ono naturalne i niezbywalne ${ }^{42}$, skutkując prawem do obrony ${ }^{43}$; każdy może zatem zrobić wszystko, co uzna za stosowne, aby siebie ocalić.

Uprawnieniem przyrodzonym, które pisarze nazywają zazwyczaj ius naturale, jest wolność, jaką ma każdy człowiek, używania swej własnej mocy wedle swojej własnej woli dla zachowania własnej istoty, to znaczy swego własnego życia ${ }^{44}$.

Prawo do obrony własnego życia w stanie natury nie ma ograniczeń, człowiek bowiem może stosować dowolne środki, które uzna za skuteczne; ma także prawo do subiektywnej oceny ewentualnych zagrożen ${ }^{45}$. W państwie nikt nie może być sędzią we własnej sprawie ${ }^{46}$, w stanie natury jednak człowiek może czynić wszystko, nie będąc winnym nawet wtedy, gdy zabije kogoś, kto jego życiu nie zagrażał; racją usprawiedliwiającą jest w tym wypadku lęk przed innymi jako potencjalnymi zabójcami.

Zdecydowanie odmiennie stan natury opisywał John Locke, zdaniem którego nikomu nie wolno traktować innych jako środka do własnych celów, ponieważ wszyscy ludzie - jako stworzeni przez Boga - są równi ${ }^{47}$. Według Hobbesa tymczasem celem nadrzędnym, usprawiedliwiającym każde działanie, jest ocalenie własnego życia. Prawo to jest jednak ograniczone, człowiek nie może bowiem czynić wszystkiego, co chce, lecz tylko to, co uzna za niezbędne dla obrony siebie ${ }^{48}$. Innym ograniczeniem jest racjonalność podmio-

\footnotetext{
${ }^{40}$ R. Tuck, Hobbes, s. 13-14.

${ }^{41}$ J. Rawls, Wykłady z historii filozofii polityki, s. 88, 101.

${ }^{42}$ A. P. Martinich, Hobbes, s. 118.

${ }^{43}$ T. Hobbes, Lewiatan, s. 215, 266.

${ }^{44}$ Tamże, s. 210-211.

${ }^{45}$ A. P. Martinich, Hobbes, s. 78-79, 118.

${ }^{46}$ Tamże, s. 99.

${ }^{47}$ S. J. Finn, Hobbes, s. 82.

${ }^{48}$ Tamże, s. 68; A. P. Martinich, Hobbes, s. 79.
} 
tu, który podejmuje zwykle tylko działania uznane przez siebie za skuteczne i rezygnuje z tych, które mogłyby być dla niego niebezpieczne ${ }^{49}$.

Środki obrony życia mogą być różne, chociażby perswazja, pochlebstwo czy sprzedanie się w niewolę. Grotius dowodził, że człowiek dla chleba jest $\mathrm{w}$ stanie stać się sługą innego ${ }^{50}$, Hobbes zaś aprobował takie rozwiązanie, uważając, że lepsza jest niewola niż śmierćs ${ }^{51}$ Przeczył zatem tezie stoików, głoszących pogardę śmierci i uznających za jedyną niewolę człowieka - lęk przed śmiercią. Pogląd Hobbesa przeczy też późniejszym wywodom Hegla, w myśl których niewolnikiem jest ten, kto za wszelką cenę chce ratować własne życie, panem zaś ten, kto nie boi się śmierci, gotów polec $\mathrm{w}$ walce o uznanie. Według Hobbesa bowiem człowiek walczy raczej o przetrwanie niż o uznanie, a podstawą takiego zachowania jest biologiczny instynkt ${ }^{52}$.

Oddanie się w niewolę nie jest jednak skutecznym środkiem obrony siebie, poddając się bowiem innym narażamy się na agresję z ich strony. Skuteczniejszą metodą jest okazanie siły ${ }^{53}$, zwłaszcza zaś zabicie potencjalnych agresorów; z prawa do życia wynika bowiem, zdaniem Hobbesa, że mogę zgładzić każdego jako potencjalnego zabójcę ${ }^{54}$. Zabójstwo okazuje się usprawiedliwioną formą obrony koniecznej, także wtedy, gdy jest czysto prewencyjne. Nikt wprawdzie nie może wiedzieć, czy inni chcą go zgładzić, ma jednak prawo takie założenie uczynićs ${ }^{55}$ Skoro zaś atak uprzedzający jest obroną skuteczną, należy go usprawiedliwić ${ }^{56}$; jeśli zatem uważam drugiego za zagrożenie dla siebie, wolno mi go zabić zanim on zabije mnie ${ }^{57}$. Prawo to mam także w odniesieniu do osób, które mi nie zagrażają; podstawą oceny sytuacji nie są bowiem dane obiektywne, lecz mój lęk przed śmiercią gwałtowną.

\footnotetext{
${ }^{49}$ M. Kuniński, Problem stanu natury, s. 121.

${ }^{50}$ R. Tuck, Hobbes, s. 29.

${ }^{51}$ T. Hobbes, Lewiatan, s. 287-289.

${ }^{52}$ Nie znaczy to, że według Hobbesa człowiek nie ma poczucia własnej godności; wręcz przeciwnie, każdy człowiek chce, aby inni cenili go w takim stopniu, w jakim on sam siebie ceni. Tamże, s. 206. Uznanie to jest jednak sprawą drugorzędną; podstawową jest zachowanie siebie.

${ }^{53}$ Mocą człowieka jest bowiem także strach, jaki budzi u innych. Tamże, s. 166.

${ }^{54}$ „[...] w takim stanie rzeczy każdy człowiek ma uprawnienie do każdej rzeczy, nawet do ciała drugiego człowieka”, tamże, s. 211. Por. też: T. Tulejski, Rozum czy uczucia? Ustanowienie porządku społecznego i politycznego według Davida Hume 'a, [w:] Z. Rau, M. Chmieliński (red.), Umowa społeczna i jej krytycy, s. 350; A. P. Martinich, Hobbes, s. 64.

${ }^{55}$ T. Hobbes, Lewiatan, s. 215.

${ }^{56}$ J. Rawls, Wykłady z historii filozofii polityki, s. 101-102.

${ }^{57}$ S. J. Finn, Hobbes, s. 68, 86.
} 
Zabójstwo prewencyjne potencjalnego agresora dopuszczał także Morus, ograniczał je jednak do relacji między państwami; sądząc, że najskuteczniejszą obroną jest atak uprzedzający, zalecał zgładzenie wrogiego władcy jako sposób uniknięcia wojny ${ }^{58}$. Według Hobbesa prawo do zabójstwa prewencyjnego przysługuje wszystkim, co jest istotnym poszerzeniem tradycyjnego prawa do zabójstwa w obronie własnej, głoszącego, że każdemu wolno zabić napastnika wtedy, gdy wszystkie inne środki ratowania siebie zostały wyczerpane ${ }^{59}$.

W stanie natury mamy jedynie uprawnienia a nie obowiązki ${ }^{60}$, zabójstwo zaś nie jest złem ani niesprawiedliwością ${ }^{61}$. Skoro bowiem nie obowiązują żadne zakazy, to każdy ma prawo do wszystkiego, posiada jednak „, [...] tylko to, co może sam zdobyć, i na tak długo, jak długo może to utrzymać w swej mocy" ${ }^{2}$. Nie istnieje zatem naturalne zło ani dobro, a rolę sumienia odgrywa instynkt przetrwania. Hobbes podzielał przy tym zasadę Grotiusa, w myśl której należy przyjąć jedynie niezbędne minimum praw, zezwalających człowiekowi bronić własnego życia. Grotius uważał przy tym, że wystarcza norma negatywna - wzajemnego niekrzywdzenia ${ }^{63}$; Hobbes tymczasem prawo do życia rozumiał pozytywnie - jako zgodę na wszystko, co może mnie ochronić. Stanowisko Hobbesa jest także odmienne od poglądu Locke `a, głoszącego, że nikt nie ma prawa zabić innego tylko po to, by ocalić siebie. Powodem różnicy była odmienność opisu stanu natury u obu filozofów; Locke akcentował naturalną równość wszystkich ludzi, którzy nie są wrogami, Hobbes zaś akcentował konflikt między pragnieniem życia poszczególnych jednostek.

Przyznając ludziom nieograniczone prawo do działań ratujących własne życie, Hobbes dostrzegał zarazem jego nieskuteczność. Jeśli bowiem każdy

\footnotetext{
58 T. More, Utopia, przeł. K. Abgarowicz, Warszawa 2001, s. 184-185.

59 Taką wersję przyjmował m.in. Tomasz z Akwinu. Hobbes uważał tymczasem, że w stanie natury można zabić innych, nawet, jeżeli nie nastają bezpośrednio na nasze życie, ponieważ samo ich istnienie jest dla nas potencjalnym zagrożeniem.

${ }^{60}$ Hobbes nie twierdził, że mamy obowiązek zachowania własnego życia czy zabicia tych, którzy nastają na nasze życie; mamy jednak takie prawo. Obowiązki wobec siebie, zwłaszcza obowiązek życia, Hobbesowi musiałby się wydać bezprzedmiotowy, ponieważ każdy z nas chce żyć. Do problemu tego wrócimy w części drugiej artykułu, rozważając problem prawa do samobójstwa.

${ }^{61}$ T. Hobbes, Lewiatan, s. 208-209. „Gdzie nie ma nad ludźmi jednej wspólnej mocy, tam nie ma prawa; a gdzie nie ma prawa, tam nie ma niesprawiedliwości”. Tamże, s. 210.

62 Tamże.

${ }^{63}$ R. Tuck, Hobbes, s. 26, 29.
} 
ma prawo zabić każdego, to o przetrwaniu decyduje siła i spryt ${ }^{64}$. Wówczas jednak powszechne prawo do zabijania nie chroni nikogo, lecz stanowi dla wszystkich największe zagrożenie, sprawia bowiem, że nikt nie jest w stanie skutecznie bronić się przed innymi ${ }^{65}$. Największa wolność i najszerszy zakres uprawnień powodują zatem, że człowiek nie może z nich korzystać. Prawo do wszystkiego okazuje się bezprawiem, wolność absolutna zaś absurdem, oznacza wszak, że każdy może zabić każdego ${ }^{66}$. W tej sytuacji „życie człowieka jest samotne, biedne, bez słońca, zwierzęce i krótkie" ${ }^{\prime 67}$. Ponieważ nikt nie może chcieć kontynuacji tego stanu, ludzie poszukują bardziej skutecznego środka obrony; jest nim umowa społeczna ${ }^{68}$.

3. Umowa społeczna. Według Hobbesa już w stanie natury powstają więzi społeczne, „[...] nie ma bowiem innej drogi, na której człowiek mógłby sobie zabezpieczyć życie i wolnośćc ${ }^{69}$. Egoizm nie jest zatem absolutny, zmuszając do tworzenia wspólnot, gwarantujących każdemu realizację własnych interesów $^{70}$. Niektórzy sadzą jednak, że idea takich stowarzyszeń prowadzi do sprzeczności, ponieważ na gruncie teorii Hobbesa stan natury i stan umowy wykluczają się: albo mamy do czynienia ze stanem natury, w którym nie ma żadnych umów, albo podjęta została umowa, która automatycznie znosi stan natury $^{71}$. Do istoty umowy należy też, że nie jest ograniczona do określonej grupy, lecz obejmuje wszystkich; skoro zaś nie jest powszechna, to trudno ją uznać za obowiązującą. Sugerowanej sprzeczności można jednak uniknąć, wyróżniając dwie formy stanu natury - pierwotny, oznaczający brak jakichkolwiek praw i umów oraz wtórny, oznaczający ograniczenie wojny powszechnej, dzięki tworzeniu małych grup, celem obrony jednostek wchodzących w ich skład; tę drugą formę można uznać za naturalny stan przejściowy między pierwotnym stanem natury a państwem ${ }^{72}$.

Niezależnie od statusu owych wspólnot, wskazują one na konieczność umowy jako jedynego środka, który skutecznie chroni wszystkich; „[...] stan

\footnotetext{
${ }^{64}$ A. P. Martinich, Hobbes, s. 108.

${ }^{65}$ Tamże, s. 86.

${ }^{66}$ T. Hobbes, Lewiatan, s. 299.

${ }^{67}$ Tamże, s. 207.

${ }^{68}$ T. Hobbes, Lewiatan, s. 181.

${ }^{69}$ Tamże.

70 A. P. Martinich, Hobbes, s. 17.

${ }^{71}$ M. Kuniński, Problem stanu natury, s. 124.

${ }^{72}$ A. P. Martinich, Hobbes, s. 78.
} 
wojny, czyli stan natury, wymusza na jednostkach kooperację w celu ochrony przed śmiercią i grabieżą"73. Sprzymierzanie się ludzi jest według Hobbesa niezbędne do obrony przed potencjalnymi agresorami, nade wszystko zaś - do ustanowienia powszechnie obowiązującego prawa. Na dłuższą metę bowiem nasze życie może zostać ocalone tylko dzięki trwałej instytucji, gwarantującej bezpieczeństwo ${ }^{74}$. Umowa okazuje się naturalną konsekwencją stanu pierwotnego, co sugeruje, że tak, jak niektóre namiętności (pożądliwość) prowadzą do wojny, tak inne (lęk przed śmiercią) prowadzą do poszukiwania pokoju i tworzenia państwa ${ }^{75}$. Naszym głównym celem jest zatem ustanowienie silnej i skutecznej władzy, której wszyscy okażą posłuch ${ }^{76}$. Taka wizja powstania państwa jest zgodna $\mathrm{z}$ geometrycznym modelem nauki, polegającym na dedukowaniu wniosków z oczywistych przesłanek; konieczność umowy wynika bowiem z lęku przed śmiercią gwałtowną i niemożliwości obrony życia w pojedynkę. Ostatecznym źródłem państwa jest zatem śmiertelność 77 , co oddaje słowo commonwealth, oznaczające grupę ludzi, którzy wybierają spośród siebie osobę mającą ich bronić ${ }^{78}$.

Lęk przed śmiercią okazuje się zjawiskiem dwuznacznym; z jednej strony skłania (i uprawnia) do zabijania innych jako potencjalnych agresorów, $\mathrm{z}$ drugiej - prowadzi do tworzenia wspólnot i budowania pokoju ${ }^{79}$. Podobnie dwuznaczny jest rozum, z jednej bowiem strony poszukuje narzędzi zgładzenia innych, z drugiej - środków porozumienia.

Dzięki rozumowi ludzie mogą również zdystansować się wobec aktualnej sytuacji i uznać stan pokoju za korzystniejszy, gdyż zapewniający skuteczniej-

${ }^{73}$ M. Kuniński, Problem stanu natury, s. 125.

${ }^{74}$ A. P. Martinich, Hobbes, s. 110.

${ }^{75}$ F. C. Copleston, Historia filozofii, t. 5, s. 35.

76 „Pragnienie wygodnego życia i zadowolenia zmysłowego skłania ludzi do tego, iżby okazywali posłuch istniejącej władzy." T. Hobbes, Lewiatan, s. 179.

77 Tamże, s. 210, 285; M. Kuniński, Problem stanu natury, s. 122. W przeciwieństwie do innych teoretyków prawa w nowożytności, Hobbes wywodzi je z naszej śmiertelności i pragnienia przetrwania. J. B. Schneewind, Montaigne on moral philosophy and the good life, [w:] U. Langer (ed.), The Cambridge Companion to Montaigne, Cambridge 2005, s. 220.

${ }^{78}$ A. P. Martinich, Hobbes, s. 40. Dlatego też konkretne umowy podpisywane z powodu lęku przed śmiercią są ważne. T. Hobbes, Lewiatan, s. 285. O wyjątkach od tej reguły piszemy w części drugiej artykułu.

${ }^{79}$ A. P. Martinich, Hobbes, s. 87, 94. 
sze i mniej kosztowne podtrzymanie życia i zmniejszenie prawdopodobieństwa gwałtownej śmierci ${ }^{80}$.

Rozum nie formułuje zatem celu działania, szukając jedynie środków jego realizacji; jego rolą „[...] jest wskazanie, jak urzeczywistnić fundamentalne pragnienie przetrwania" ${ }^{\text {. }}$.

Jak źródłem umowy jest lęk przed śmiercią gwałtowną, tak jej celem jest obrona ludzkiego życia; nie jest on maksymalistyczny (wygoda) ${ }^{82}$, lecz minimalistyczny (zmniejszenie groźby śmierci gwałtownej) ${ }^{83}$. Umowa ma pomóc człowiekowi w zachowaniu życia i owoców jego pracy ${ }^{84}$, przyświeca jej zatem cel osiągalny ${ }^{85}$. Nie daje ona człowiekowi nowych uprawnień (w stosunku do stanu natury nawet je ogranicza) $)^{86}$, gwarantuje jednak egzekwowalność prawa do życia.

Umowa może być skuteczna tylko pod warunkiem, że przystąpią do niej wszyscy $^{87}$. Jest to możliwe, ponieważ jej przepisy dotyczą jedynie zewnętrznych zachowań, a nie intencji, myśli czy wierzeń. Wprawdzie zatem sumienie musi być poddane temu, co publiczne, nie niszczy to jednak wolności prywatnej, na przykład w zakresie myśli czy wierzeń, każdy ma bowiem prawo wierzyć w cokolwiek ${ }^{88}$. Umowa jest także możliwa do przestrzegania przez każdego, powstrzymanie się bowiem od zabijania innych nie przekracza moralnych kompetencji żadnej osoby ${ }^{89}$. Będąc skuteczniejszą od zbrojenia się i walki, umowa zwiększa moc każdej jednostki ${ }^{90}$; chociaż bowiem nie stanowi gwarancji absolutnej (nie wyklucza możliwości jej złamania), to jednak

\footnotetext{
${ }^{80}$ M. Kuniński, Problem stanu natury, s. 121.

${ }^{81}$ F. C. Copleston, Historia filozofii, t. 5, s. 35.

${ }^{82} \mathrm{~J}$. B. Schneewind, Montaigne on moral philosophy and the good life, s. 220.

${ }^{83}$ T. Hobbes, Lewiatan, s. 215, 253.

${ }^{84}$ Tamże, s. 419, 430.

${ }^{85}$ S. J. Finn, Hobbes, s. 90.

${ }^{86}$ A. P. Martinich, Hobbes, s. 90. Wprawdzie nie mogę już czynić tego, co uważam za słuszne w obronie siebie, ograniczenie to dotyczy jednak tylko środków obrony, nie zaś prawa do życia.

${ }^{87}$ T. Hobbes, Lewiatan, s. 212, 215; „[...] wszelka umowa jest przeniesieniem wzajemnym, czyli wymianą uprawnień", tamże, 218.

${ }^{88}$ A. P. Martinich, Hobbes, s. 230. W skrajnym przypadku nawet skryte życzenie komuś śmierci nie byłoby złamaniem umowy, pod warunkiem, że nie było publicznie wygłaszane i nie skutkowało żadnym innym działaniem mogącym na daną osobę sprowadzić zagrożenia.

${ }^{89}$ Y. Abosch, The Conscientious Sovereign: Public and Private Rule in Thomas Hobbes 's Early Discourses, „American Journal of Political Science” 50 (2006) 3, s. 623.

${ }^{90}$ T. Hobbes, Lewiatan, s. 163, 166.
} 
radykalnie zmniejsza ryzyko śmierci gwałtownej ${ }^{91}$. Jej skuteczność zależy także od sankcji przewidywanych za jej zerwanie, musi zatem być tak sformułowana, aby niedotrzymanie jej nie mogło być korzystne.

Mogłoby się jednak wydawać, że - przynajmniej w sytuacjach wyjątkowych - lepiej złamać umowę niż jej dotrzymać; skrajny egoista bowiem skuteczniej realizuje swoje cele w społeczeństwie altruistów. Skoro zaś - na gruncie teorii Hobbesa - liczy się moje indywidualne przetrwanie, to mam prawo korzystać z wszystkich dostępnych środków. Hobbes dopuszczał zresztą, że osoba, która osiąga sukces za pomocą działań niesprawiedliwych, może zostać usprawiedliwiona ${ }^{92}$.

Wbrew temu jednak złamanie umowy nie jest korzystne dla osoby, która się go dopuściła. Powodem nie są represje ze strony władzy, lecz wspólny interes wszystkich; nikt bowiem nie będzie tolerował jednostki, która w społeczeństwie dotrzymującym umowy, ciągle ją łamie. Każdy też, kto łamie umowę, w rzeczywistości dąży do stanu natury, czyli do wojny wszystkich ze wszystkimi, która również dla niego stanowi zagrożenie ${ }^{93}$. Skoro zaś złamanie umowy prowadzi do utraty bezpieczeństwa, a nawet życia, ewentualna korzyść jest iluzoryczna; może być zatem, co najwyżej, przypadkowa i doraźna ${ }^{94}$.

Umowa nie daje nowego prawa, lecz gwarantuje egzekwowanie tych, które przysługują nam z natury, suweren bowiem przekształca je w prawo państwowe ${ }^{95}$ (czyli prawo w sensie ścisłym ${ }^{96}$ ). To, co było zasadą przyrody, staje się regułą społeczną, obowiązującą na mocy rozkazu. Od tej pory nie jesteśmy zdani tylko na siebie, lecz zyskujemy ochronę instytucjonalną, ponieważ odpowiedzialność za obronę naszego życia ponosi władza.

Kwestią sporną pozostaje źródło prawa, ponieważ Hobbes uznawał prawo natury za wyraz woli Boga ${ }^{97}$. Teologiczne uzasadnienie prawa jest jednak

${ }^{91}$ M. Kuniński, Problem stanu natury, s. 122.

${ }^{92}$ A. P. Martinich, Hobbes, s. 102.

${ }^{93}$ T. Hobbes, Lewiatan, s. 242.

${ }^{94}$ A. P. Martinich, Hobbes, s. 103-104. Znaczy to, że umowy należy przestrzegać z racji egoistycznych. Y. Abosch, The Conscientious Sovereign, s. 627.

${ }^{95}$ S. J. Finn, Hobbes, s. 95.

${ }^{96}$ Prawo oznacza słowo tego, który ma uprawnienie do rozkazywania innym. T. Hobbes, Lewiatan, s. 243.

${ }_{97}$ A. P. Martinich, Hobbes, s. 221. A. E. Taylor w artykule The Ethical Doctrine of Hobbes przekonywał, że uzasadnienie prawa ma u Hobbesa charakter teologiczny, odwołuje się bowiem do wiary w Boga. D. M. Jesseph, Hobbes Atheism, „Midwest Studies in Philosophy” 26 (2002), s. 141 , p. 2, s. 161. 
zbędne, jego treść bowiem nie ulega zmianie, niezależnie od tego, czy uznamy je za zasadę przyrody, regułę ustanowioną przez władzę czy objawioną przez Boga. Sankcja religijna nie zmienia zakresu ani charakteru naszych uprawnień i obowiązków, nie wpływa też na sposób ich obowiązywania ${ }^{98}$. Prawa mamy przestrzegać nie dlatego, że wierzymy w jego boskie źródło, lecz dlatego, że zostało ogłoszone przez władcę świeckiego i stoi na straży naszego interesu. Władca musi jednak zadbać, żeby ustanowione zasady były zgodne z prawem natury, które jest wieczne i niezmienne, obowiązując wszystkich w każdym czasie; według Hobbesa bowiem prawa sprzeczne z prawem natury nie mogą być słuszne ${ }^{99}$. Ostatecznie zresztą treść wszystkich praw redukuje się do podstawowej zasady, nakazującej dążyć do pokoju i zezwalającej bronić siebie wszelkimi możliwymi środkami ${ }^{100}$. Z jednej bowiem strony to właśnie pokój najskuteczniej pozwala nam realizować naturalny cel, jakim jest zachowanie własnego życia; z drugiej jednak - jeśli pokój jest zagrożony - musimy podjąć walkę w obronie własnej. Umowa, która nie gwarantuje człowiekowi prawa do obrony siebie, jest nieważna, ponieważ

żaden człowiek nie może przekazać swego uprawnienia do tego, by bronić się przed śmiercią, ranami i uwięzieniem, ani go się zrzec (uniknięcie tych rzeczy jest wszak jedynym celem zrzekania się jakiegokolwiek uprawnienia) ${ }^{101}$.

Prawa do życia nie tylko nie można się zrzec, lecz należy w nim widzieć zakaz czynienia tego, co prowadzi do śmierci ${ }^{102}$; znaczy to, że przyrzeczenie, iż nie będę stawiał oporu agresorom, nigdy mnie nie wiąże ${ }^{103}$. Istnieje zatem granica ludzkich umów, wyznaczająca „pewien obszar ludzkiej wolności obejmującej rzeczy, do których prawo nie może zostać przeniesione na drodze ugody" ${ }^{104}$. Należą do nich środki niezbędne do przetrwania, jak po-

\footnotetext{
${ }_{98}$ Tamże, s. 142, 163; J. Rawls, Wykłady z historii filozofii polityki, s. 76.

${ }^{99}$ T. Hobbes, Lewiatan, s. 242.

${ }^{100}$ Jest to pierwsze i podstawowe prawo natury, głoszące, że „każdy człowiek winien dążyć do pokoju, jak dalece tylko ma nadzieję go osiągnąć, a gdy go osiągnąć nie może, wolno mu szukać wszelkich środków i rzeczy dlań korzystnych w wojnie i ich używać”. Tamże, s. 212. W innym miejscu Hobbes streszcza wszystkie prawa w postaci potocznej i lakonicznej formuły: „nie czyń drugiemu tego, czego byś nie chciał, iżby ten drugi czynił tobie”. Tamże, s. 241.

${ }^{101}$ Tamże, s. 223.

102 J. Rawls, Wykłady z historii filozofii polityki, s. 127, 156. Prawo natury zakazuje mi czynić to, co jest szkodliwe dla mojego życia. T. Hobbes, Lewiatan, s. 231.

103 Tamże, s. 223.

${ }^{104}$ S. Kijaczko, Wobec bycia, s. 133.
} 
żywienie czy lekarstwa, nade wszystko zaś - sama wola życia ${ }^{105}$. Jeśli zatem w czasie klęski głodu człowiek kradnie pożywienie celem zachowania życia, jego działanie jest usprawiedliwione ${ }^{106}$.

4. Relatywizm. Stanowisko Hobbesa bywa określane mianem relatywizmu moralnego ${ }^{107}$, skoro bowiem w stanie natury nie istnieją obiektywne kryteria dobra i zła ani też uniwersalne powinności, to treść pojęć moralnych zależy od przekonań i emocji poszczególnych ludzi ${ }^{108}$. Dobrem jest to, co dana osoba uważa za swoją korzyść (i czego pragnie), złem zaś to, co jest przeciwne jej interesom (i czego chce uniknąć) ${ }^{109}$. Ponieważ jednak nie wszyscy pragną tego samego (a nawet ta sama osoba ma różne pragnienia zależnie od czasu i okoliczności) ${ }^{110}$, relatywizm jest nieuchronny ${ }^{111}$.

Zdaniem niektórych komentatorów uniwersalnym i obiektywnym kryterium moralności nie jest także dążenie do zachowania życia ${ }^{112}$. Powodem jest to, że Hobbes dopuszczał, iż niektórzy ludzie mogą chcieć śmierci; nie każdy zatem uważa życie za dobro, chcąc je zachować. Gdyby zaś nawet każdy czynił wszystko, aby śmierci uniknąć, to zachowanie takie mogłoby oznaczać jedynie konieczność faktyczną, wynikającą z praw przyrody, a nie moralną powinność; z tego bowiem, że wszyscy przestrzegają określonej reguły, nie wynika, iż jest ona obowiązkiem. Obowiązki istnieją dopiero z chwilą ustanowienia prawa przez władzę, wtedy jednak dobro i zło zależą od arbitralnej woli suwerena; gdyby zmienił on prawo, zmianie uległaby także treść pojęć

\footnotetext{
105 Tamże.

106 T. Hobbes, Lewiatan, s. 387-388. Hobbes tego wątku nie rozwinął, sugerował jednak, że w takiej sytuacji dopuszczalne byłoby nawet okradanie ubogich; klęska głodu przypomina bowiem stan powszechnej wojny, usprawiedliwiając wszelkie działania, podjęte dla ratowania własnego życia.

107 Tuck twierdzi nawet, że jednym z celów etyki Hobbesa była obrona relatywizmu. R. Tuck, Hobbes, s. 60, 62. Hobbes był oskarżany o relatywizm od samego początku, zwłaszcza przez przedstawicieli kościoła anglikańskiego. Za relatywistę uważał Hobbesa także znany badacz jego myśli Leo Strauss. Tamże, s. 115.

108 Tamże, s. 62-63; S. J. Finn, Hobbes, s. 6.

109 Tamże; A. P. Martinich, Hobbes, 57.

${ }^{110}$ R. Tuck, Hobbes, s. 66.

${ }^{111} \mathrm{~W}$ The Elements of Law relatywizm Hobbesa zdaje się sięgać głębiej, oznaczając nie tylko względność pojęć moralnych, lecz także względność pojęcia człowieka. Pisząc bowiem o zniekształconych noworodkach, o których nie wiemy, czy są ludźmi, Hobbes stwierdza jednoznacznie, że decydująca powinna być w takich wypadkach arbitralna decyzja suwerena. R. Tuck, Hobbes, s. 129.

112 S. J. Finn, Hobbes, s. 65.
} 
dobra i zła ${ }^{113}$. Szczególnie wyraźnie widać to na przykładzie różnic między systemami prawnymi poszczególnych państw.

Wbrew tym argumentom stanowisko Hobbesa relatywizmem nie jest. Jeśli bowiem nawet ludzkie pragnienia są różne, to przynajmniej jedno jest wspólne wszystkim - pragnienie zachowania swego życia ${ }^{114}$. Sugeruje to, że śmierć jest obiektywnym złem, życie zaś obiektywnym dobrem, przynajmniej w sensie biologicznym i gatunkowym. Można zatem powiedzieć, że prawo do życia jest naturalne i uniwersalne, nadając pojęciom dobra i zła obiektywną treść; dobrem jest to, co służy zachowaniu życia każdej jednostki, złem zaś to, co je uniemożliwia lub utrudnia. Na płaszczyźnie pojęć zatem oraz nadrzędnego celu naszych działań relatywizmu nie ma.

Niebezpieczeństwo relatywizmu mogłoby pojawić się, co najwyżej, na płaszczyźnie środków realizacji celu, ten sam czyn bowiem, który jednemu życie ratuje, a drugiemu je odbiera, byłby zarazem dobry i zły. Nawet jednak w takiej sytuacji relatywizm ma granice; jeśli bowiem wszyscy mają ten sam cel (zachować życie), to muszą podjąć działania gwarantujące sukces każdemu. Musi zatem powstać wspólnota przestrzegająca przynajmniej zakazu zabijania jako obiektywnego zła.

Relatywizmu moralnego nie dowodzi też pragnienie śmierci, które może wynikać z braku rozpoznania, co jest dobrem i złem; utrata życia zaś na pewno dobrem nie jest, wyklucza bowiem możliwość osiągnięcia wszelkich dóbr. $\mathrm{Z}$ drugiej strony, nawet samobójstwo nie przeczy pragnieniu zachowania życia; osoba je podejmująca wybiera bowiem nie tyle kres życia, ile kres cierpień.

Na gruncie teorii Hobbesa trudno odróżnić opis od normy, ponieważ instynkt przetrwania jest naturalnym mechanizmem, usprawiedliwiającym każde działanie przyczyniające się do zachowania życia. Skoro jednak mamy naturalne pragnienie życia, to każde prawo, które zezwalałoby (a tym bardziej - nakazywałoby) odebrać życie dowolnej osobie, byłoby złe, a nawet nie mogłoby zostać uznane za prawo. Według Hobbesa bowiem prawo musi

\footnotetext{
113 Tamże, s. 65-66, 85.

${ }^{114}$ Hobbes wskazuje tylko na jedną sytuację, w której człowiek mógłby chcieć umrzeć; byłoby tak wtedy, gdyby władca nakazał synowi zabić ojca. Wówczas jednak pragnienie śmierci wynikałoby z dramatycznego wyboru, do którego człowiek został zmuszony, a nie z utraty woli życia czy instynktu przetrwania. Do przykładu tego wrócimy w części drugiej.
} 
umożliwić realizację podstawowego pragnienia życia, które staje się w ten sposób obiektywną normą postępowania ${ }^{115}$.

Eliminacja relatywizmu jest także zadaniem państwa ${ }^{116}$. Władca ma obowiązek ustanowić prawo, które będzie skutecznie broniło życia poszczególnych obywateli; obowiązuje ono jednak nie tylko dlatego, że jest wyrazem arbitralnej woli, lecz także dlatego, że chroni wszystkich. Odkąd zatem istnieje państwo, nie ma już niebezpieczeństwa relatywizmu środków; nikt przecież nie może odtąd bronić siebie w sposób dowolny, lecz podlega wspólnej ochronie instytucjonalnej.

Nie ma również groźby relatywizmu kulturowego ani prawnego, według Hobbesa bowiem natura ludzka jest niezmienna. Skoro zaś ludzie pragną tego samego, to - niezależnie od różnic między systemami prawnymi poszczególnych państw - każdy władca musi ustanawiać zasady skutecznie chroniące życie wszystkich. $Z$ tego powodu nie mogą one być sprzeczne z prawami natury, stanowiącymi uniwersalną i obiektywną podstawę prawa państwowego. Tylko głupi zatem może twierdzić, że nie ma sprawiedliwości ${ }^{117}$; sprawiedliwość wszak to przestrzeganie prawa, czyli także własnego interesu (którego prawo broni). Jeśli zaś ktoś przeczy sprawiedliwości, to nie tylko sam chce działać wbrew prawu, lecz godzi się, że inni będą działać podobnie. Wtedy jednak naraża siebie, żadnego bowiem działania podjętego przeciwko sobie nie będzie mógł nazwać złym; skoro bowiem nie ma sprawiedliwości, to nie ma również niesprawiedliwości (bądź też - każdy ma prawo do działań niesprawiedliwych). Osoba negująca istnienie sprawiedliwości widzi zatem tylko własną korzyść z łamania prawa, zakładając, że inni będą ustalonych zasad przestrzegać. Jej głupota polega więc na tym, że nie potrafi rozpoznać warunków realizacji swego interesu, dążąc do stanu powszechnej wojny, której sama może być ofiarą ${ }^{118}$. Tymczasem, jeśli ktoś dotrzymuje zobowiązań wobec

${ }^{115}$ Finn uważa ją raczej za normę roztropności niż normę moralną. S. J. Finn, Hobbes, s. 74$-75,77$.

${ }^{116}$ R. Tuck, Hobbes, s. 74-75. To przezwyciężenie relatywizmu ma się dokonywać na różnych płaszczyznach, nie tylko prawnej czy moralnej. Istotna jest także płaszczyzna języka, Hobbes uważał bowiem, że z racji konwencjonalności znaczeń, to władca ma ostateczny głos w sprawie sposobu użycia poszczególnych słów. Musi zatem arbitralnie ustalić ich ścisłe definicje, dzięki czemu usunie konflikty między ludźmi, wynikające często właśnie z odmiennego rozumienia wyrażeń.

${ }^{117}$ S. J. Finn, Hobbes, s. 73. Sformułowanie to odnosi się do Księgi Psalmów, która nazywa głupim osobę przeczącą istnieniu Boga; obraz ten wykorzystał święty Anzelm w apriorycznym dowodzie istnienia Boga.

118 Tamże, s. 74. 
mnie, to ja nie mam powodu, aby nie dotrzymać umowy z nim, zwłaszcza, gdy przynosi to korzyść obu stronom ${ }^{119}$. Wspólny interes zatem, jako cel umowy, okazuje się granicą relatywizmu.

Jak lęk przed śmiercią gwałtowną leży u podstaw umowy społecznej, tak naturalne prawo do życia wymusza konkretne regulacje, gwarantujące możliwość jego egzekwowania. Nie usuną one metafizycznej trwogi przed unicestwieniem, nie gwarantują bowiem nieśmiertelności, mogą jednak zmniejszyć lęk przed śmiercią gwałtowną. Jednym zatem z głównych zadań władcy jest ustanowienie zakazu zabijania. Wówczas jednak powstaje problem, czy są uzasadnione wyjątki od tego zakazu, chociażby w postaci kary śmierci. Równie ważne jest pytanie o jego zakres - czy dotyczy on także samobójstwa, czy jedynie działań wobec innych osób. Z kolei z samobójstwem wiąże się problem moralnej dopuszczalności ofiary w obronie życia innych bądź bezpieczeństwa państwa. Kwestie te są przedmiotem drugiej części artykułu.

\begin{abstract}
Death as a Source and an Object of Law. Thomas Hobbes' Stantpoint

(Part I: Death as a Source of Law)

The article reconstructs and evaluates Hobbes' argumentation concerning establishing of law and specific rules regarding death. In the first part (Death as a Source of Law) the problem of fear of death as a foundation of law is considered, in the second (Death as an Object of Law) specific regulations concerning killing in self-defence, the capital punishment, rules of war, martyrdom, rationality of sacrifice for another person and of suicide will be pointed out.
\end{abstract}

119 R. Tuck, Hobbes, s. 79. 